\title{
NOTES FOR A LECTURE ON THE LAW OFFICERS AND THE LORD CHANCELLOR
}

\author{
LORD HAILSHAM*
}

Lord Hailsham was a visiting speaker at the Faculty of Law, University of Alberta in early 1978. He graciously agreed to write this article on English Law Officers, a subject he was most eminently qualified to write as a former Lord Chancellor of England.

I was originally asked to deliver this lecture on the subject of the office of Attorney General or the Law Officers. To this subject I add the office of Lord Chancellor, 1 partly because I had practical experience of it, but more especially because the wider questions raised by the subject which has been chosen for me require a consideration of all the main responsibilities discharged by Ministers with legal responsibilities in the Government.

It is, of course, notorious that parliamentary democracy means Government by amateurs. The Secretary of State for Education is almost never a head teacher, the Secretary for Defence only exceptionally a general, air marshal or admiral. The Chancellor of the Exchequer almost never a banker.2 The expertise is provided by others. They are not even professional administrators. They are there to give political direction.

To this general rule there is one broad exception. The Attorney and Solicitor General for England, the Lord Advocate and Solicitor General for Scotland, ${ }^{3}$ and the Lord Chancellor are all lawyers and ought to be lawyers ${ }^{4}$ of experience and distinction, the first four from the practising bars of their respective countries, the last either from the Bar or the Bench. They are all politicians, and therefore responsible for Government policy. The Lord Chancellor is always in the Cabinet and must nowadays be a Member of the House of Lords. The two English Law Officers must always be members of the House of Commons, and Scottish Law Officers always were until successive Governments found recruitment difficult. They differ from their colleagues in so far that in each case each supplies his own expertise, and places at the service of his office his professional judgment and experience. Thus they share the resonsibilities and the responsibility to Parliament of all Ministers but in this one vital characteristic they differ from their colleagues, in this fundamental sense their responsibility is dual; perhaps more accurately hybrid. They are professional men as well as politicians in office.

You must not expect to find their responsibilities absolutely consistent or absolutely logically confined. This is true of all traditional institutions which have grown up stage by stage in the course of history. All have the marks of their historical development still visible among their modern responsibilities. The Lord Chancellor's office antedates the Norman Conquest. It is so old that there is no legal requirement that it's incumbent should be legally qualified, and as late as the reign of Charles I one was a bishop. The Attorney Generalship

* The Right Honourable Lord Hailsham of Marylebone, C.H., F.R.S., D.C.L., Member of the British House of Lords. 
and the Office of Solicitor General under these names date from the fifteenth century. There is no legal requirement that they should be in the House of Commons, indeed their original place in Parliament was on the judges' woolsack in the House of Lords. They are still summoned separately to that assembly, and though they never attend as such even at the opening of Parliament a vestigial relic of their function in the House of Lords was seen only a short time ago when the Attorney General presented to the Committee of Privileges the case in the disputed peerage case concerning the Ampthill Barony. After the Act of Union, the Lord Advocate was practically the adminstrative ruler of Scotland until the creation of a separate Secretary of State for Scotland in the latter part of the nineteenth century, and some administrative functions not attaching to his English counterpart still adhere to him.

At first sight these peculiar characteristics may seem anomalous and even illogical, and for those more concerned with appearance than reality it may be so. But I hope to show you in a moment that this is illusion. All countries have Ministers of Justice called by whatever name. But no two countries give to such Ministers exactly the same functions, ${ }^{5}$ and in truth the difficulty in a democracy of combining Parliamentary responsibility with judicial and juristic independence is not an easy one. In most countries Ministers of Justice combine responsibility for prosecution with responsibility for Court administration and judicial appointments. In my view this is highly inappropriate. They are separate functions, and in my view responsibility for judicial appointments is incompatible with that for prosecutions. In England, and, subject to what I shall be saying hereafter, we give responsibility for prosecutions to the Attorney General, and judicial appointments to the Lord Chancellor who, since my own Chancellorship, now assumes responsibility for Court Administration, with which it is conveniently combined. In my judgment it could also conveniently be combined with responsibility for criminal and civil evidence and procedure. In fact, in my view illogically, we give civil procedure and evidence to the Lord Chancellor (an appropriate arrangement), but (in my view inappropriately) criminal evidence and procedure to the Home Secretary as often as not who has no professional qualifications and in any event owes no professional duties. In many countries, if not most, Ministers of Justice combine responsibility for prosecutions with responsibility for police and penal treatment. In my view this is also inappropriate. They are three separate functions. Police and penal treatment are compatible and, in my view appropriately, rest with the Home Secretary. 6 Prosecutions as I have said, come within the sphere of the attorney. Both would be incompatible with the appointment of judges and court administration which, as I have also said, rightly rest with the Lord Chancellor. Thus, although it cannot be said that the frontiers are exactly evidently drawn, we have a distinct advantage in separating prosecutions on the one hand from police and penal treatment on the other, and equally rightly Courts and Court Administration in attend.

These are positive gains though you will notice that I have said nothing about responsibility for commercial law, which rests with the Department of Industry, for the law of employment labour relations 
and apprenticeship, which rests with the Employment Ministry, the law of the road which rests with transport under the Secretary for the Environment and so on and so forth. Nor will you observe is there any departmental responsibility for the general progress of law reform as such, nor for the general drafting of Statutes (the Parliamentary draftsmen, who answer directly to the Prime Minister). These are arcane matters, and it is perhaps inevitable that there should be many fingers in these pies. So I will return to the Attoreny General, whose responsibilities are the main subject of this lecture.

I said just now that the Attorney General was responsible for prosecutions. In so far as he has to answer in Parliament for the conduct of the prosecution process this is literally true. To use the jargon, he is the sponsoring Minister. But how far is he exactly in charge? And in so far as he is in charge, how does he discharge his responsibility? To answer these questions it is at once necessary both to expand and to qualify my original statement. As a general rule, prosecutions in England and Wales are not under a single centralized authority. They are conducted by County Councils, by police chiefs, Factory or School Inspectors, and Education Authorities, the Royal Society for the Prevention of Cruelty to Animals, the National Society for the Prevention of Cruelty to Children, by private citizens like Mr. Francis Bennion who prosecuted Peter Hain in the cricket case. The Attorney General can, it is true, initiate prosecutions. In a number of statutory exceptions, his consent is necessary before a prosecution, whether private or public is launched. In all indictable cases, it is open to him to stop any prosecution, private or public by entering what is called a a nolle prosequi.? He can take over any prosecution already launched and continue to conduct or discontinue it on behalf of the Crown. He is also responsible for supervising the work of the Director of Public Prosecutions, through whom he normally discharges these functions when he personally intervenes, but who, in theory is not part of the law officers' department, and in practice operates largely independently to prosecute in serious cases and almost always in the cases of homicide, and takes over appeals to the House of Lords. As a practising barrister, the Attorney General used to appear in Court on behalf of the Crown in Prosecutions. He still occasionally does so, but usually now, even where he does appear himself or nominates the Solicitor General to do so, he usually instructs other leading counsel as well to deal with the case when, as normally happens, he or his colleague is called away to deal with his other duties. The old practice, according to which he or the Solicitor always prosecuted personally in poisoning cases, has, I think effectively lapsed.

As I have said, in serious matters, the Attorney General is called upon to advise whether a prosecution should be launched. It is important to emphasize that in discharging this responsibility he does so as an independent authority separately advising the Crown. His political colleagues may not interfere with his discretion, and his decision when it is made does not come under the doctrine of collective responsibility. ${ }^{8}$ When the proceedings are at an end so that the $s u b$ judice rule no longer applies to Parliament procedure, he may be questioned in Parliament and even censured for the use of his discretion, but such censure is not censure of the Government. 
It used to be said that this discretion is quasijudicial in character. I do not myself like the phrase which is used of many public responsibilities not directly political in character but in some ways it is convenient, and I do not know of another. What it really means is two quite separate things. In the first place the Attorney cannot be directed by his political colleagues. In the second place, his discretion must take account of what in his judgment is the public good or the public interest. The first proposition was finally established at the time of the Campbell prosecutions when the first Labour Government under Ramsey Macdonald tried and failed to establish the proposition that the Attorney General might only initiate prosecutions with political implications with the consent of the Cabinet. This contention, which led to the fall of the Labour Government, is now universally condemned. The second, that the Attorney General is bound to have regard to the public interest requires closer examination.

It is universally accepted that the public interest should not include party political considerations, or the political consequences to his colleagues in the administration of his decision one way or the other. This really follows from the doctrine established after the Campbell case itself. But it by no means follows from this that the Attorney General should not take into account considerations which may be considered political in a broader sense difficult to define, or that he may not consult with individual colleagues or the Cabinet as to what the consequences to the public interest of the initiation or discontinuance of the prosecution may be. In some cases these may include questions of public view, in others the effects on our international relations. But in exercising this consideration, he has to balance the importance of enforcing and therefore vindicating law and the rule of law against the other imponderables. In this lecture I have no space for the discussion of individual cases, but I must refer here to the case of the world be murderess Leila Khaled who was mercifully foiled in her activities by the El Al Security Officers and landed forcibly at Heathrow shortly after I became Law Chancellor. In that case the decision rested with the Attorney General and he did discuss and consult the matter with his colleagues collectively and individually as he was entitled to do, making it clear all the while that the decision was his and his alone and that he would not welcome or indeed tolerate interference with it. I therefore do not know what ultimately influenced him. But clearly he must have considered the chances of securing a conviction on a more serious charge from a mere breach of the immigration rules, the importance of putting down hijacking and enforcing the rule of law, the effect of a successful, and of an unsuccessful prosecution on our relations with various other States, neutral, Arab and Israeli, and other matters. He would not have been entitled to consider either his own reputation or that of the fairly newly formed Government of which he was a member or his colleagues, or the political party to which he belonged.

Another allied but totally distinct responsibility rests with the Attorney General in his responsibility for enforcing the general law, criminal and civil, by civil proceedings. This responsibility was recently highlighted by the proceedings brought in the civil courts by 
Mr. Gourliet against the Union of Post Office workers for an injunction. The general law affecting this situation has long been clear. Against an actual or apprehended breach of the general law it is plain that the Attorney General has the right, and in suitable cases the duty of enforcing the law by injunction or declaration where an ex post facto prosecution is not considered effective. A private individual may do so if his particular interests are affected, for example, if someone digs up the road outside my house without lawful authority. But a private individual has no automatic status to bring such proceedings as a village Hampden. For example, a London resident would not normally be entitled to bring a similar proceeding against an exactly similar infraction in a street in Liverpool. He can, of course, prosecute if any offence is committed. But he may not bring civil proceedings in his own name to restrain by injunction an offence not yet committed. In order to do this he has first to secure the consent of the Attorney General (called a fiat) to initiate the proceedings in the Attorney General's name. Sir Peter Rawlinson once gave such permission on the relation of an individual named Macwhirter. The present Attorney General, Mr. Silkin, refused his on the application (known technically as the relation) of $\mathrm{Mr}$. Gourliet. Mr. Gourliet then sought to bypass Mr. Silkin by direct application to the Courts, judge in Chambers, Court of Appeal. He succeeded in the Court of Appeal but lost in the House of Lords when Mr. Silkin appealed. This lecture is no place to question Mr. Silkin's use of his discretion. He could have been censured in Parliament after the proceedings were over, but was not. What was established was that he was not to be censured, nor was his use of discretion to be questioned, in the Courts. Since, in the nature of things, I was not asked to sit on this appeal, I think I am entitled to say that I have no doubt whatever that the decision of the House of Lords was right, and that, although he might well have exercised his discretion differently, my father would certainly as Attorney have taken the same stand as Mr. Silkin vis-a-vis the Court of Appeal had he exercised his discretion in the same way.

The Attorney General, and the Solicitor, have always been the principal legal advisors to the Crown. In the nineteenth century this function was largely exercised by the giving of formal opinions, for which, incidentally, at that time the Law Officers were separately remunerated by fee in the usual way. These joint opinions, when they touched on international questions were often published, and occasionally still are, and form an important source for the state of international law at the time they were given. The Law Officers of the Crown, although now remunerated solely by salary occasionally give opinions to departments and others in the old way. More often their opinion is sought, and obtained, less formally, by telephone, orally, by letter, by attendance at Cabinet, question and answer in the House and by other means. A great part of a modern law officer's time is consumed in the House of Commons, in Committee and on the House floor. Here again he is expected to perform a dual, or at least a hybrid, role. He is the spokesman for the Government on legal matters, and often employed in a purely political role to defend awkward questions of policy including those which, not normally being a Cabinet member, he has had no part in framing. But on purely legal questions, the meaning or 
effect of a clause, or proposed amendment to the Bill he is expected to place his legal expertise at the disposal of the House and not just of his colleagues. He is expected to answer truthfully to the best of his skill and understanding as a professional adviser with the House as his client.

I made a brief mention a moment ago of the method of remuneration of the Law Officers. Until a comparatively late date in the nineteenth century the Law Officers were remunerated, like other counsel, by fees only, and, as these were decisively small, were permitted to top up their earnings by private practice. This was obviously open to objection and from, I believe, the eighteen eighties until the tenure of office by Sir Hartley Shawcross, Law Officers were excluded from private practice, but, in addition to their fees, which, though they were increased were still much lower than contemporary fees paid by private solicitors, were paid a retaining salary in addition. They are now remunerated solely by salary, but, as before, they remain practising members of the Bar. This enables the Attorney to retain his position as Leader of the Bar, though much of the glory has departed and now rests on the corporate personality of the Senate and Bar Council. But he still nominates Counsel in public prosecutions and civil proceedings and the Treasury Counsel at the Old Bailey.

As the legal adviser to the Crown in its capacity as parens patriae the Attorney General also retains a certain responsibility for charities, and, until recently for infants. He has also had one new function added to him in recent years. Under the Crown Proceedings Act, 1947 he is the nominal defendant in civil proceedings against the Crown when no other Minister can be appropriately impleaded. He also appears as Counsel for the Crown in important proceedings before the International Court at the Hague, The European Court at Strasbourg, and the European Community Court at Luxembourg.9

Until comparatively late in the nineteenth century the Law Officers had no proper departmental staff. There is now a small, efficient, but numerically inadequate Law Officers Department, supplemented by the professional advice of the Treasury Devils in the various divisional fields, the Treasury Solicitors, the Treasury Consul at the Old Bailey, and in infant cases the Official Solicitor, who comes, however, for administrative purposes under the Lord Chancellor.

I think at this stage I had better leave the Law Officers in what is necessarily a general tour of their duties and constitutional position. I leave them with one further point of a general nature. From the seventeenth century onwards the Law Officers of the Crown have been seriously overworked, and, compared with other leading members of the Bar fantastically underpaid. They must therefore be comparatively young, and because they cannot endure the pace too long, have reasonably looked to judicial appointment to protect their old age. For many years until the post was abolished the Chief Justiceship of the Common Pleas was looked upon, indeed known as, the Attorney General's cushion or pillow. Until comparatively recently, indeed perhaps until the retirement of Lord Goddard, it was supposed by many that the Attorney General of the day had the first refusal of the office of Master of the Rolls or Lord Chief Justice if either fell vacant during his period of office. This was unpopular with the Press and public, and, 
in theory, no doubt could not be defended. It has however been increasingly difficult to recruit leading members of the Bar into politics. They are reluctant to add to the burdens of practice the additional and onerous duties of service in the House of Commons, and constituency parties have become in recent years increasingly reluctant to select leading lawyers as candidates.10 Since from what I have said it is obvious that the responsibilities of the Law Officers' position are so important that it is manifestly undesirable that the posts should be held by anyone other than a lawyer of the top quality, with a real political sense, and political experience behind him, this must obviously give rise to anxiety for the future. More than is generally appreciated, the efficient working of Government and even of Parliament itself depends on the quality of the Law Officers of the Crown and the availability of suitable alternatives in the event of resignation or a change of Government. One can only hope that these anxieties can be allayed.

I have only left a little time to deal with the office of Law Chancellor. It would be preferable to devote a separate lecture to this subject, and perhaps one day I may have the opportunity to do so. I have only insisted on adding some account of this office to this lecture, because in my view he is a key constitutional figure, and because the omission to describe his duties in a lecture on the Law Officers would give a very false impression of our constitutional duties. I will, however, confine myself to his position in the constitution and omit for this reason a very large number of his miscellaneous duties important as these may be.

The Office of Lord Chancellor is the oldest under the Crown except the Archibishop of Canterbury, and antedates, by several centuries. both the Norman Conquest and therefore Parliament itself. It has always been a political office, and only gradually developed a mainly legal and judicial character. The early chancellors were in effect the Prime Ministers under a Monarch. The last such Chancellor, born out of due time, was Clarendon. The judicial functions gradually developed out of the use of the great seal to issue equitable remedies, from which it occurred that the main legal functions of the Chancellor up to and including the time Eldon, and perhaps Brougham and Lyndhurst were as judges of first instance. A vestige of this function is the position of the Chancellor as the nominal head of the Chancery Division, and the bestowal upon the Senior Court Room of that division of the honorific description of "Lord Chancellor's Court".

For a time during the eighteenth century the Stanoverian Monarchs employed the Chancellors, particularly Thurlow and Eldon, as their private agents in the Cabinet, and occasionally employed them to intrigue against their Prime Ministers or other colleagues. I need not say that this function wholly disappeared after Eldon ceased to hold the great seal. It was perhaps the last relic of the Prime Ministorial function of the early Chancellors.

The importance of the modern post lies in the fact that he is the connecting link between the two surviving branches of Government in modern Britain, the political and the juridical. The Church has now ceased to be part of the political establishment, and the executive and legislature are now for most purposes virtually fused. But the 
Courts and the judiciary still retain a precarious hold upon the independence they achieved as the result of the Bill of Rights and Act of Settlement. The real constitutional duty of a Lord Chancellor is to preserve that independence, as need be at the cost of his own reputation and career. Other civilised countries have a written constitution preserving this independence, either by political or constitutional safeguards, or by judicial review through a Supreme Court or by other means. But we have no written constitution. We therefore have to depend on a man. He must be a man who is a sufficient lawyer to command the respect and loyalty of the judges. He must also be a man who is enough of a politician to command the respect and even to some extent to inspire the fear of his colleagues and opponents in Government and legislature. He must be immune from the day to day turbulence and violence in fighting in the House of Commons. But, because he must be responsible to Parliament it is right that he should possess a seat in the legislature in the House of Lords, and because he must command the respect of the judiciary and lest some future Prime Minister should be tempted to appoint some party hack to the post without the independence, the integrity, or the necessary scholarship to defend the position it is vital that he should submit to the discipline and utilize the right to give judgment in the matters of the highest importance in the House of Lords.

When I was Lord Chancellor, I was constantly asked whether we did not need a Minister of Justice in this country. I as constantly answered that we did and that the Lord Chancellor was that Minister. But I as constantly added that though the administration of the Courts and the appointment of judges were among his essential functions he should neither be responsible for prosecutions, penal treatment, police nor possess a seat in the House of Commons. I adhere to that opinion to day. There are some functions that $I$ added to the responsibility of the Lord Chancellor's office, notably the administration of the Criminal Courts and there are some others which I think should be added. There are other functions which I endeavoured to drop less or more successfully. But so long as democracy requires a Court system and a Bench independent of political terrors, and at least as long as we have no written constitution, I believe that an official with the main characteristics of the Chancellorship is the best guarantee that a country can have that justice will be done according to law without fear or favour, affection or ill will. 